\title{
Prophetic Chemo Is the Safest, Cheapest and Most Effective Alternative to Modern Chemotherapy for the Cure of all Forms of Cancers - A Review
}

\section{Hussain AS Deena ${ }^{1}$ and Muhammad Musharraf Hussain ${ }^{2 *}$}

${ }^{1}$ Department of Biochemistry, Shaheed Monsur Ali Medical College, Uttara, Dhaka, Bangladesh

${ }^{2}$ Department of Pharmacy, Manarat International University, Ashulia, Prophetic Medicine Foundation, Dhaka, Bangladesh

\begin{abstract}
Like all other great Prophets (as) of Allah (God), statements of the Prophet (peace be upon him) of Islam are divinely inspired. Prophet Muhammad (PBUH) never spoke a single lie in his lifetime. Whatever he spoke was under divine inspiration. Concerning his statements and utterances Allah says in the Qur'an:

"He does not speak anything on his own. It is but a Revelation which is sent down to him" (An-Najm 53:3-4).

"And if Muhammad had made up about Us some [false] sayings, we would have seized him by the right hand; then We would have cut from him the aorta" (Al-Haqqah, 69: 44-46).

So, traditions of the Prophet (PBUH) on healing are also true, which modern science proves through research after 14 centuries. Although the Prophet's mission was neither as a physician or pharmacist, he was inspired by God to make nearly 1000 statements on healing for the benefit of humankind because man needs to remain well free from sickness to fulfill his brief mission on earth. About Nigella sativa Abu Hurayrah (ra) narrates that the Prophet (PBUH) said:

"Hold on (use this seed regularly)! Because it is a remedy (cure) for every disease except death." (Bukhari, Muslim)

This amazing statement of the Prophet (PBUH) generated tremendous interest among the world scientific community, which finally led them to carry out extensive biological and phytochemical investigations on the plant seed. However, the researchers after carrying out hundreds of studies in various countries finally concluded that black seed can effectively cure 129 different types of ailments including 17 types of cancers. This large number of diseases curable by black seed demonstrates the authenticity of the Prophet's statement.

In this paper the learned readers will be informed about the beneficial pharmacological effects of Nigella sativa in the treatment of most human ailments as well as the findings of modern scientific researches on how Prophetic chemo isolated from Nigella sativa can effectively cure numerous cancers without any side effects.
\end{abstract}

Keywords: Nigella sativa oil and extract; Black seed; Black cumin; Thymoquinone; Cancer; Prophetic medicine; Anti-cancer drug

\section{Introduction}

Chemotherapy is the use of any drug to treat any disease. But to most people, the word chemotherapy means drugs used for cancer treatment. It's often shortened to "chemo." Surgery and radiation therapy remove, kill, or damage cancer cells in a certain area, but chemo can work throughout the whole body. Cancer treatment depends on the type of cancer, the stage of the cancer (how much it has spread), age, health status, and additional personal characteristics. There is no single treatment for cancer, and patients often receive a combination of therapies and palliative care. Attempts to cure or palliate cancer employ several basic methods. Treatments usually fall into one of the following categories: surgery, radiation, chemotherapy, immunotherapy, hormone therapy, or gene therapy. It is reported that cancers account for $20-25 \%$ of deaths in clinical practices [1-4].

Koehnlechner and Barbounaki-Konstantakou report that modern chemotherapy is based on the systemic administration of anticancer drugs that travel throughout the body via the blood circulatory system [5,6]. In essence, chemotherapy aims to wipe out all cancerous colonies within the patient's body, including metastasized cancer cells. However, research reveals that the majority of the most common cancers are not curable with chemotherapy alone. This kind of treatment also has many side effects, such as nausea, anemia, weakening of the immune system, hair loss, diarrhea and vomiting. Finally, cancer cells may develop resistance to chemotherapeutic drugs.

\section{Most commonly used chemo drugs}

In April 2016 American National Cancer Institute at the National Institute of Health USA published an updated A to Z list of 469 drugs currently used as chemo for treating 39 different types of cancer, out of these the following ones are commonly used. Surprisingly none of these drugs is free from harmful side effects.

Flurouracil, Amsacrine, Asparaginase, Bleomycin (Bleoxane ${ }^{\circ}$ ), Capacitabine, Carboplatin, Cisplatin, Cyclophosphamide,

*Corresponding author: Muhammad Musharraf Hussain, Professor, Department of Pharmacy, Manarat International University, Permanent Campus Ashulia Dhaka and Founder President, Bangladesh Prophetic Medicine Foundation, 44/6 Middle Paikpara, Mirpur, Dhaka, Bangladesh, Tel: +88-01912583439; Fax: +8802 8917978; E-mail: dmmhqiabd@gmail.com

Received March 21, 2018; Accepted May 02, 2018; Published May 04, 2018

Citation: Deena HAS, Hussain MM (2018) Prophetic Chemo Is the Safest Cheapest and Most Effective Alternative to Modern Chemotherapy for the Cure of all Forms of Cancers - A Review. J Cancer Sci Ther 10: 090-104. doi: 10.4172/1948-5956.1000525

Copyright: (c) 2018 Deena HAS, et al. This is an open-access article distributed under the terms of the Creative Commons Attribution License, which permits unrestricted use, distribution, and reproduction in any medium, provided the original author and source are credited. 
Cyclophosphamide, Cytarabine (Ara-C), Dacarbazine, Daunorubicin $\left(\right.$ Cerubidine $\left.^{\circledast}\right)$, Docetaxel, Doxorubicin (Adriamycin $\left.{ }^{\circledR}\right)$, Epirubicin (Ellence ${ }^{\circledast}$ ), Etoposide, Etoposide (VP-I6, Vespid $\left.{ }^{\star}\right)$, Gemcitabine, Ifosphamide, Irinotican, Mercaptopurine (6-MP), Methotrexate, Mitomycin (Mutamycin $\left.{ }^{\star}\right)$, Nelarabine, Teniposide (Vumon $\left.{ }^{\star}\right)$, Oxaliplatin, Paclitaxel, Pazopanib (VOTRIENT ${ }^{\circledR}$ ), Pemetrexed, Temozolomide, Tioguanine, Vimblastine and Vincristine.

\section{Common harmful side effects of modern chemotherapy}

Modern chemotherapy drugs are powerful enough to kill rapidly growing cancer cells, but they also can harm perfectly healthy cells, causing side effects throughout the body. Chemotherapy and its side effects add to the stresses of everyday life. Drugs for chemo affect people in different ways. They also affect other vital body organs. Not everyone has the same side effects with the same drug. About the common side effects of chemotherapy American Cancer Society on Feb 15, 2016 reports the following.

Fatigue, hair loss, easy bruising and bleeding, Infection, anemia (low red blood cell counts), nausea and vomiting, appetite loss, edema, delirium, constipation, diarrhea, mouth, tongue, and throat problems such as sores mouth and mouth ulcer, peripheral neuropathy, pain with swallowing, nerve and muscle problems such as numbness, tingling, and pain, skin and nail changes such as dry skin and color change, urine and bladder changes and kidney problems, weight changes, chemo brain (mental cloudiness), which can affect concentration and focus, mood changes, changes in libido (men and women) and sexual function and fertility problems [7].

\section{What does a modern chemo do?}

Most cancer patients are weak and have lack of appetite. This lack of appetite causes them not to eat properly. Once the patient goes one or two days without eating properly in stage III or IV, the cancerous cells have a chance to cause more damage, spread faster and destroy what good cells are left. Modern chemotherapy does the same thing. Chemotherapy works by stopping or slowing the growth of cancer cells, which grow and divide quickly. Chemo destroys what good cells are left, including the cancerous cells and after the chemo treatment is done, the body becomes so weak and may not recover as predicted. Warning labels, "Modern chemotherapy produces secondary cancers", do not convince cancer patients at all. They are so frightened and convinced that in absence of alternative effective cancer cure, modern chemo is their only solution. They will forgo danger signals of modern chemo drugs and go for the single most powerful thing that will kill them eventually. It is stated that at times the patient does not die of cancer, dies from chemo.

\section{Modern chemotherapy produces secondary cancers}

There have been numerous scientific evidences that many chemo drugs produce secondary cancers. It has been reported that some types of chemotherapy (chemo) drugs have been linked with different kinds of second cancers. The cancers most often linked to chemo are myelodysplastic syndrome (MDS) and acute myelogenous leukemia (AML). Sometimes, MDS occurs first, then turns into AML. Acute lymphocytic leukemia (ALL) has also been linked to chemo. It has further been reported that 'Chemo' is known to be a greater risk factor than radiation therapy in causing leukemia. Some solid tumor cancers have also been linked to chemo treatment for certain cancers, such a testicular cancer.

It has further been reported that for the growing number of survivors of Hodgkin's lymphoma (HL), secondary cancer is a leading cause of death. For female HL survivors, breast cancer is the most common second malignancy, and several studies have defined the incidence and relative risk of second breast cancer in women treated for HL. The cumulative incidence increases with young age at initial treatment, radiation dose, radiation therapy (RT) field size, and time from treatment, and approaches $25 \%$ to $30 \%$ in a woman age 55 years who was treated for HL at age 25 . This increased risk of breast cancer emerges approximately 10 years after primary therapy and persists beyond 25 years of follow-up.

Dr. Otis Brawley, chief medical officer at the American Cancer Society answers a question on "Could chemo drugs cause a second malignancy?" He answers: It is ironic but true that many cancer chemotherapies are known to cause cancers. It is something that the physician must consider when recommending treatment. Nurses and pharmacists who mix and administer cancer chemotherapies take precautions to minimize their exposure to these drugs because of the potential for harm [8].

\section{What is prophetic chemo?}

The bioactive compound 'Thymoquinone (TQ)' is the prophetic chemo for the cure of cancer. This natural chemo drug, isolated from Nigella sativa seed is approved by Prophet Muhammad (PBUH) as a very effective cure and modern scientists support it through scientific researches. Prophet Muhammad (PBUH) did not need to carry out any scientific research to state that black seed is a cure for every disease except death. His statement was divinely inspired. However, since the statement was made 1400 years ago, thousands of researches have been carried out around the globe to prove the authenticity of the Prophet's statement as well as effectiveness of Thymoquinone (TQ) in the treatment of human cancer. The drug has no side effects whatsoever. However, FDA and WHO have not yet approved the drug for commercial use (Figure 1).

The Arabic name of Nigella sativa Linn. is Habbatus Sawda or 'Habbat al Baraka'. The name Nigella sativa comes from the Latin word, nigellus, meaning black. It is translated as 'Seeds of Blessing. The seed is called black cumin or black seed in English, while in old Latin it was called 'Panacea' meaning 'cure all'. It is known as 'Kalijeera' (Bangladesh), 'Kalonji' (in India) and 'Hak Jung Chou' (China). The Common English name for Nigella sativa is Love in a Mist. Nigella sativa belongs to the Ranunculacae family.

\section{Biblical and Qur'anic references to Nigella sativa (black seed)}

An earliest written reference to black seed is found in the book of Isaiah in the Old Testament, where it is referred as "ketzah", a spice for bread and cakes that can be used in many ways. (Isaiah 28: 25, 27 NKJV). However, no reference for its use in the treatment of human ailments is found in the Bible. Similarly, no reference to black seed or<smiles>CC1=CC(=O)C(C(C)C)=CC1=O</smiles>

Figure 1: Prophetic chemo (Thymoquinone, TQ). 
Citation: Deena HAS, Hussain MM (2018) Prophetic Chemo Is the Safest, Cheapest and Most Effective Alternative to Modern Chemotherapy for the Cure of all Forms of Cancers - A Review. J Cancer Sci Ther 10: 090-104. doi: 10.4172/1948-5956.1000525

black cumin is mentioned in the Qur'an. Only the Prophetic traditions make reference to the use of this plant seed (Figure 2).

\section{Medicinal uses of Nigella sativa}

Although the anti-cancer activity of Nigella sativa was recognized thousands of years ago, it was not until the past two or three decades that modern scientific research has been undertaken to study this important traditional medicine. Nigella sativa is among the most commonly used herb in the history of mankind. The use of this seed as a healing herb has been traced back more than 3000 years to the Assyrians and ancient Egypt. Traditional folk medicine has been safely using black seeds since the time of the ancient civilizations. Nigella sativa is considered by many to be a "miracle" herb due to its effective therapeutic potential to alleviate signs and symptoms of many diseases including cancer. The Prophet (PBUH) made specific statements on 61 medicinal plants, herbs and shrubs while making prescriptions for the sick people, out of which Nigella sativa is the most important [8].

\section{Literature review and Aim of Present Study}

Apart from the common side effects of modern chemo usually experienced by cancer patients during the treatment, post therapy complications of modern chemo are also very severe. The treatment is also very expensive, varies from $\$ 5000$ to $\$ 20,000$ or even more if treatment is done abroad, which ordinary people cannot afford. It also continues over a long period of time. Conventional therapy needs from 1 to 3 years. That is why more and more people are now looking for alternative cancer cures. Prophetic chemo is one of such alternative cancer cures.

The success rate of modern chemotherapy is very low. Most chemo drugs also produce secondary cancers. On the other hand, recent research shows that Prophetic chemo does not cause any harmful side effect. It is absolutely safe and natural. In this paper we shall make a clear comparison between these two types of chemo from scientific points of view and highlight the benefits and advantages of Prophetic chemo over modern chemo. We then come out with a recommendation as to why Prophetic chemo is the safest, cheapest and most effective alternative cancer cure.

In the next few pages we shall discuss about alternative cancer cure (Prophetic chemo), and the published work so far done on the usage and beneficial effects of Prophetic chemo.

\section{Published Books on Nigella sativa Linn. (Black seed, Black cumin)}

\section{Published books on black seed}

Information from the United States data bank states that more than 150 books and articles have been written in recent times by professionals about the physical and chemical properties of black seed. Likewise, extensive research continues in many universities and health research centers in the Islamic world as well as in Western non-Muslim countries with regard to the many healing qualities of black seed. Due to the great importance attached to the plant seed the following seven books have been recently published.

1. "Healing Power of Black Cumin" by Sylvia Luetjohann, Twin Trees, WI: Lotus Light Publications, 1998, A Handbook on Oriental Black Cumin Oils, Their Healing Components and Special Recipes, 156 pages.

2. "Black Cumin: The Magical Egyptian Herb for Allergies, Asthma, Skin Conditions and Immune Disorders" by Dr. M. Saleh (Egypt) and P. Schleicher (Germany), Rochester, VT: Healing Arts Press, 2000, 90 pages.

3. "Black Seed: The "Miracle Herb" of the Century" by W. G. Goreja, published by Amazing Herbs Press, Jan 1, 2003, 54 pages.

4. "Black Seed - A Cure For Every Disease Book", Sweet Sunnah, A Cure for Every Disease But Death - A comprehensive guide to understanding and application of one of the most powerful healing herbs in the world, 40 Pages.

5. "The Benefits of Black Cumin, Black Cumin / Black Seed / Nigella Sativa - Cure to All Diseases Revealed" by C ALBER, published by Tulip Publisher Group, 08/01/2012.

6. "Black Seeds (Nigella sativa) - The Miraculous Healing Power for all Diseases", Publisher: Um Hurairah, 01/01/2012.

7. “The Black Cumin Cancer Protocol” - Step-by-Step Guidelines by Maria Hurairah, Barnes \& Noble, 07/17/2014.

\section{Plants that fight cancer}

Spiridon E. Kintzios and Maria G. Barberaki have edited a book titled, Plants That Fight Cancer, which has been published by CRC PRESS LLC. 2000 N.W., Florida 33431 in 2004 (314 page) [9]. This book contains information obtained from authentic and highly regarded sources. A wide variety of references are listed. In the book it was reported that Nigella sativa seeds contain thymoquinone (TQ) and dithymoquinone (DIM), which were cytotoxic in vitro against MDR human tumor cell lines. It made the following research reference [10-12].

\section{Review of Recently Published Research Work on the Anti-Cancer Effects of Prophetic Chemo}

Treatment of cancer using prophetic chemo is the safest,

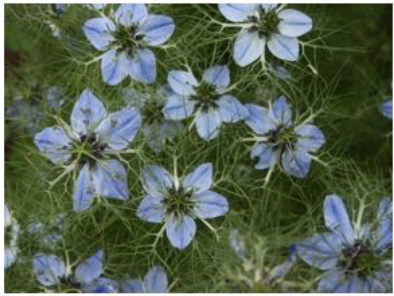

Black cumin flower

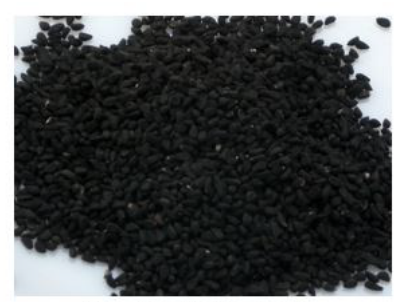

Black cumin seed

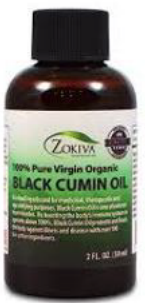

Black cumin oil

Figure 2: View of black cumin flowers, seeds and cumin oil. 
cheapest and most effective alternative to modern chemotherapy and radiotherapy. There have been numerous modern scientific research findings in support of this statement. They are described below for understanding of the learned readers and researchers.

In the recent past, Thymoquinone (Prophetic chemo) has been studied extensively for its anti-oxidant [13], anti-carcinogenic and anti-mutagenic properties $[14,15]$. Thymoquinone is a relatively safe compound, particularly when given orally to experimental animals [16]. Much of the biological activities of the seeds have been shown to be due to Thymoquinone, which is also present in the fixed oil $[17,18]$. Thymoquinone has been shown to inhibit the proliferation of a wide variety of tumor cells including breast adenocarcinoma, ovarian adenocarcinoma [19], colorectal cancer [20], human pancreatic adenocarcinoma, neoplastic keratinocytes [12], human osteosarcoma [21], fibrosarcoma [22,23], lung carcinoma [24] and myeloblastic leukemia [25].

\section{Thymoquinone in the eye of world class scientists}

A book titled nutrition, diet and cancer, edited by Professors Dr. Rakesh K. Srivasta and Sharmila Shankar of University of Kansas Medical Center, Kansas City, USA has been published by Springer in 2012. The ISBN and e-ISBN of the book are 978-94-007-2922-3 and 978-94-0072923-0 respectively. In the book Banerjee [26] wrote chapter 4 named 'Molecular Insight and Preclinical Perspective of Thymoquinone' as Chemo Preventive Agent and Chemotherapeutic Adjunct in Cancer (page 84 - 107). They enumerated a detailed account of the scientific researches so far done on the bioactive compound, 'Thymoquinone', along with its use in the treatment of numerous cancers. Each page of the chapter is full of research references on the pharmacological effects of Thymoquinone (Prophetic chemo) as anticancer drug. The learned readers are requested to have a glimpse of the pages.

\section{Amazing pharmacological effects of Thymoquinone}

Recent researches carried out on Nigella sativa in various countries reveal that the bioactive compound, Thymoquinone, possesses 51 pharmacological effects, out of them the following are well known: Anticancer effects, immune regulating, anti-inflammatory, antitumorous, anti-histaminic, anti-spasmodic, anti-diabetic and antibronchitis, antioxidant, hepato-protective, analgesic, antipyretic, antimicrobial and anti-fungal, antihypertensive, antiepileptic, antimitotic and bronchodilating, anti-asthmatic, anti-parasitic, antiallergic, anti-neoplastic, ulcerative etc.

\section{Thymoquinone is the beneficial supplement for many forms of cancer}

Nigella sativa and its principal compound, Thymoquinone (TQ) have been a well-documented beneficial supplement for many forms of cancer, including pancreatic cancer. Right now, pancreatic cancer is the fourth leading cause of cancer deaths in America, because the survival rate after five years of conventional cancer treatment is sadly, only 4 percent. A study conducted at Kimmel Cancer Center, at Thomas Jefferson University, Philadelphia - revealed that Nigella sativa (black cumin) DESTROYED pancreatic cancer cells - with an incredible 80 percent cancer tumor cell death! It also showed to stop the gene transcription process so cancer cells can't replicate! [27,28].

\section{Thymoquinone from black seed induces apoptosis in leukemia}

As it has been shown to do with other types of cancer, black seed compound thymoquinone has also been shown to induce apoptosis in leukemia cells [29]. It was also reported that it kills leukemia cells in vitro. Li $\mathrm{F}$ reports that thymoquinone inhibits proliferation, induces apoptosis and chemosensitizers human multiple myeloma cells through suppression of signal transducer and activator of transcription 3 activation pathway [30]. The research identified STAT3 signaling as a target of TQ and has thus raised its potential application in the prevention and treatment of $\mathrm{MM}$ and other cancers. Researchers believe thymoquinone holds promise as a preventative strategy both for patients who have already gone through surgery and chemotherapy, as well as a promising preventative measure - especially for those genetically prone $[31,32]$.

\section{Thymoquinone is the most effective bioactive compound of black seed}

The most efficacious bioactive medicinal compound in black seed oil is called thymoquinone. In a study published in "Molecular Cancer Therapeutics" in 2008, scientists injected a low dose of thymoquinone into cancerous human prostate tumor cells in a petri dish. The proliferation of the tumor cells stopped, with no toxic side effects. No new blood vessels formed within the tumors, and they stopped growing in size. The scientists concluded that thymoquinone stops tumor growth in humans and claim it has potential as a drug for cancer therapy $[33,34]$.

\section{Thymoquinone reduces the growth and size of tumors}

According to the National Director of Naturopathic Medicine for Cancer Treatment Center of America (CTCA), Oklahoma, there is growing evidence that black cumin and its volatile oil may have anticancer properties. Anderson refers to studies to indicate the seeds active ingredients, particularly thymoquinone, which may reduce the growth and size of tumors in rats [35]. Thymoquinone has also been reported to possess in-vitro cytotoxic activity [10-12].

\section{Other potential uses of Thymoquinone}

Apart from cancer, thymoquinone was also found effective against many diseases such as cardiovascular complications, diabetes, asthma, kidney disease, etc. A literature search has revealed that a lot more studies have been recently carried out related to the anticancer activities of Nigella sativa and some of its active compounds, such as thymoquinone and alpha-hederin. Acute and chronic toxicity studies have recently confirmed the safety of Nigella sativa oil and its most abundant active component, thymoquinone, particularly when given orally. Their work summarized the extremely valuable work done by various investigators. In two separate 2011 studies the effects of Nigella sativa seed, its extracts and active principles against cancer have been reported. The scientists hoped that this review will encourage interested researchers to conduct further preclinical and clinical studies to evaluate the anticancer activities of Nigella sativa, its active constituents and their derivatives [36-38].

In 1991 a study of black seed's potential anti-tumour principles was conducted by the Amala Research Centre in Amala Nagar, Kerala, India. The results suggested the use of black seed in the treatment of cancer. United States researchers studied the effects of Nigella sativa on humans $[39,40]$.

\section{US Scientists recommend clinical trials using thymoquinone with human cancer patients}

Researchers from Wayne State University in Michigan found that their review of published reports about black seeds indicates that 
further in-depth studies are warranted. They specifically point to the need to study its bioavailability and Phase-I toxicity profiling in human subjects [41]. A researcher from Oman recommends clinical trials of thymoquinone with human cancer patients [42]. Research also shows that Nigella sativa is a potential antiosteoporosis agent [43]. The researchers reveal that Nigella sativa suppresses tumor growth and prevents need of chemotherapy.

\section{Black seed oil prevents the need for chemotherapy in cancer patients}

In a study, published in the "Brazil Journal of Medical and Biological Research" in 2007, Scientists induced cancerous tumors in rats to find the extent to which black seed oil could suppress their growth. The study reveals more compelling evidence supporting the potential role of black seed oil in preventing the need for chemotherapy in cancer patients [44].

Chiropractor Dr. James P. Urban reports that documentations from survivors showed testimonies that Nigella sativa cured a wide array of cancers including brain, bone and stomach cancer [45].

In view of the great importance of the plant seed in cancer and other human ailments, more and more scientific research results are being added everyday into the research data bank concerning clinical activity of thymoquinone. Pubmed of NCBI at the US National Library of Medicine includes large number research information on Nigella sativa in its data and resource bank (Table 1).

\section{Ancient uses of Nigella sativa for common ailments}

It has been reported that Cleopatra used black seed as its health beauty giving quality. Queen Nefertiti used black seed oil to bring luster to her hair and nails. Hippocrates used it to assist with digestive and metabolic disorders. King Tutankhamen kept a bottle of black seed oil in his tomb, presumably to protect him in the afterlife. This indicates that the oil probably had an important role in ancient Egyptian practices. Physicians in Pharaohs' times used black seed as a remedy for colds, headaches, respiratory and digestive disorders, toothaches, infections, inflammatory disorders and allergies [46].

\section{World Health Organization recently recommends black seed as an herbal remedy}

Nigella sativa is the most extensively studied plant on the face of the earth, both phytochemically and pharmacologically. It is one of the few natural, herbal remedies that found to have tremendous potential benefit. Today, more and more medical scientists and professionals are recognizing the healing power of this amazing little seed. It was recently recommended as herbal remedy by the World Health Organization [47].

\section{0 university research projects on black seed submitted for the award of degrees}

The ongoing scientific research in the West continues to show the positive results to generate excitement throughout the medical industry. So far nearly 500 university research projects on black seed have been submitted by students for the award of degrees since 1959 . This confirms the effectiveness and traditional uses of this powerful seed. Researches were carried out at major international universities and articles published in various scientific journals documenting the astonishing results of the black seed.

\section{Highest number of researches done on Nigella sativa}

Nigella sativa is the only plant on the face of the earth that has been investigated by a large number of modern scientists. Modern researches on Nigella sativa are so huge in number that one can easily verify using the literature and databases (SciFinder, Google Scholar, PubMed, ScienceDirect and Scirus). I have found that PubMed Data and Resource Bank contain a lot of recent research citations. Usually for a medicinal plant on the average 10 to 100 scientific studies or more are usually carried out to determine the active principles responsible for the pharmacological effects as well as to determine the efficacy in treating human ailments. But why there have been hundreds of research studies done on this particular plant seed? What is the reason of demonstrating such a tremendous interest on this tiny seed?

From a quick search in the internet it is assumed that as of now the number of laboratory researches so far done on this blessed plant seed and its oil in various countries of the world has gone up to approximately 10, 000 or even more. Everyday more and more research information are being added to research data bank. If one searches the research titles on Nigella sativa or thymoquinone or black seed/black cumin in all the journals published in various countries of the world he can also be able to verify the truth. Possibly because of the wonderful healing quality of the seed Professor Peter Schleicher, M.D., a renowned immunologist in Munich said,

"Calling black cumin a magical cure would certainly be an exaggeration, but it is almost impossible not to exaggerate its effectiveness" [48].

\section{Phytochemical constituents of black seed}

Recent scientific researches reveal that black seed contains over 100 phytochemical constituents and healing components, which work together to produce a synergetic effect. Out of this only sixtynine have been characterized and identified. Research has shown that this complex interaction of over 100 components gives black seed tremendous synergistic power to support the immune system and strengthen the body's constitution in a way no single substance has ever been known to accomplish. Dr. Michael Tierra LAC. O.M.D, author of Planetary Herbology, writes: "Black seed is truly a remarkable herb that has been used for over 3000 years. It contains over 100 valuable components. It is a significant source of essential fatty acids, proteins, carbohydrates and other vitamins and minerals. The seeds are also rich in sterols; especially beta-sitosterol which is known to have anticarcinogenic activity." [49].

\begin{tabular}{|c|c|}
\hline Group & Characteristics of the studied group \\
\hline 1 & Two weeks before $H$. pylori inoculation, they were daily fed the product via gavage and diet. \\
\hline 2 & Two weeks after $H$. pylori inoculation, they were daily fed the product via diet and gavage. \\
\hline 3 & They were treated with common drugs used to treat $H$. pylori for three weeks \\
\hline 4 & Control group with $H$. pylori inoculation and without treatment \\
\hline 5 & Control group without $H$. pylori inoculation and without treatment \\
\hline
\end{tabular}

Table 1: Characteristics of studied groups 


\section{Anticancer properties of Nigella sativa}

The anti-cancer properties of Nigella sativa have been mainly attributed to its ability to exert potent anti-proliferative, pro-apoptotic, anti-oxidant, anti-mutagenic, and anti-metastatic roles. Nigella sativa provides powerful benefits for various inflammatory cancers such as liver, melanoma, skin, pancreatic, cervical, breast, bone, stomach, lymphoma, prostate, colon, and brain. It has been proven with countless peer reviews to effectively treat cancer. Originally, Nigella sativa was used to treat migraines and allergies, but recent discoveries have shown that this little black seed is effective in destroying cancer cells. Not only cancer, Nigella sativa seeds have been proven to be effective in the treatment for more than 129 diseases (Hussain and Hussain, 2016). So may we humbly ask, is there any disease or ailment which is not curable by black seed? If yes, let us know the ailment so that further research could be conducted to substantiate the Prophetic statement. If not, we can precisely say that the Prophetic statement made fourteen centuries ago about black seed is one hundred per cent true (Tables 2 and 3).

\section{Black seed suppresses growth of multiple types of cancer}

A study published in "Oncology Letters" in 2010 found that two daily doses of crude extra-virgin black seed oil inhibited the growth of cancer tumors in the colon, lungs, esophagus and fore-stomach in rats [50]. The study concluded that black seed oil has carcino-preventive and chemo-preventative potential, which means that it could possibly be used to prevent cancer and lessen the need for chemotherapy in the early stage of cancer.

\section{Black seed possesses anticancer activity}

Researchers at the Department of Biochemistry, School of Biological Science and Technology, Central South University, Hunan, China and Department of Biochemistry and Molecular Biology, Philadelphia College of Osteopathic Medicine, Philadelphia, Pennsylvania, USA confirmed that black cumin possesses anticancer activity [51]. There are several research reports from African Journal of Traditional, Complementary, and Alternative Medicines.

\section{Nigella sativa oil has proven successes in cancer therapy}

The Cancer Immuno-Biology Laboratory of South Carolina, USA ran a series of experiments in which mice were infected with tumor cells. Two thirds of the animals treated with Black Seed Oil were still alive thirty days after being infected. In contrast, all of the mice that did not receive Black Seed treatment died in this time period [52]. Similarly encouraging results come from experiments with human bone marrow cells and tumor cells: a 250 percent increase of bone marrow cells and an almost 50 percent reduction in the growth of tumor cells were directly attributed to the effects of the Black Seed Oil therapy. The ingestion of Black Seed Oil is thus an effective support for every cancer therapy [48].

In 1997, researchers at the Cancer Research Laboratory of South Carolina, USA have further proved that Nigella sativa oil had enormous success in tumor therapy without the negative side effects of common chemotherapy. The report stated that a healthy immune system will detect and destroy cancer cells and concluded that the oil is an ideal candidate for use in cancer prevention and cure [53-55].

\section{Nigella sativa is the most inexpensive treatment protocol for the management of cancer}

It has been reported that there are over 400 different protocols for cancer treatment and some are extremely expensive. Nigella sativa protocol is not only simple and easy to use, but it is also very inexpensive [56].

In fact, Nigella sativa is one of the most inexpensive treatment protocols currently available in the market for the management of cancer. Egyptian researchers reported that combined use of black seeds and honey has been found to eliminate liver cancer cells. The researchers also found that both honey and black seed extract were effective in reducing the viability of liver cancer cells.

Recently, Chinese and Saudi Arabian researchers reconfirmed the anti-cancer property of this safe and natural black seed oil [51]. The researchers reviewed the scientific literature for the use of black seed oil with cancer. They reconfirmed the anti-cancer property of this safe and natural seed oil. Researchers also concluded that black seed is a safe and effective agent against cancer in the blood system, lungs, kidneys, liver, prostate, breast, cervix, and skin.

\section{Black seed extract treats cancer tumours}

In October 1999, the European Magazine of Cancer published an article on the effect of thymoquinone on abdomen cancer in rats. The results of many modern researches supported the findings of Qâdi. It was reported that amongst the findings are the results published by the International Immunity Magazine in August 1995 about the effect of black seed on the outer lymph cells and the activity of white blood multi-nucleus cells [54].

\begin{tabular}{|c|c|c|c|c|c|}
\hline \multicolumn{2}{|c|}{ Primer Name } & $5^{\prime}$ to $3^{\prime}$ Sequence prime & Product size (bp) & Annealing temperature $\left({ }^{\circ} \mathrm{C}\right)$ & References \\
\hline \multirow[t]{2}{*}{$\operatorname{cag} A$} & $\mathrm{~F}$ & AATACACCAACGCCTCCAAG & \multirow{2}{*}{$400 \mathrm{bp}$} & \multirow{2}{*}{55} & \multirow{2}{*}{ Izadi et al., 2012} \\
\hline & R & TTGTTGCCGCTTTTTGCTCTC & & & \\
\hline \multirow[t]{2}{*}{ urec } & $\mathrm{F}$ & AAGCTTTTAGGGGTGTTAGGGGTTT & \multirow{2}{*}{$294 \mathrm{bp}$} & \multirow{2}{*}{55} & \multirow{2}{*}{ De Negreiros Bessa et al., 2014} \\
\hline & $\mathrm{R}$ & AAGCTTACTTTTCTAACACTAACGC & & & \\
\hline
\end{tabular}

Table 2: The primer used in this study

\begin{tabular}{|c|c|c|c|}
\hline Group & Type of tests & Inflammation intensity & Pathological changes \\
\hline 1 & Intaking probiotic products two weeks before inoculation & 1 & $\begin{array}{c}\text { A small number of leukocytes dispersed in depth of mucus and inflammation and mild } \\
\text { degradation of mucus }\end{array}$ \\
\hline 2 & Intaking probiotic products two weeks after inoculation & 2 & $\begin{array}{l}\text { Average number of leukocytes in depth or middle of the mucus and sometimes } \\
\text { neutrophils in the glands and mild inflammation in the mucosa and under the mucosa }\end{array}$ \\
\hline 3 & Intaking the usual treatment 2 weeks after inoculation & 1 & Mild mucus degradation \\
\hline 4 & Control (bacterial inoculation) & 3 & $\begin{array}{l}\text { Dense leukocyte infiltration in depth or middle of the mucosa and mild degradation of } \\
\text { the mucosa in the anteroom tissue }\end{array}$ \\
\hline 5 & Control & 0 & Without change \\
\hline
\end{tabular}

Table 3: Scale of gastric inflammation of the studied rats in intervention groups 
Likewise, in May 1998, Anticancer Res, a magazine specialized in anti-cancer researches published an article on the extracts of black seed as a treatment for cancer tumors. On April 2000, the Ethanol Medical Magazine wrote about the toxicity and immunity effects of ethanol extract from black seeds. Also, in February 1995, Medical Plants magazine published an article on the effects of the black seed stable oil and thymoquinone on white blood cells. Medenica and her research team of International Immuno-Biology Research Laboratory, South Carolina, 29926 reports an interesting research finding that black seed oil fights cancer [57].

\section{Advantages of Prophetic Chemo over the Modern Chemo}

\section{Prophetic chemo has no harmful side effects}

Prophetic chemo has no side effects or adverse reactions, no feeling of tiredness or weakness, no sign of being sick, no short-term or long-term post therapy complications, no diarrhea and vomiting, no sexuality and loss of fertility in men and women, no hair loss (alopecia), no mouth sore and mouth ulcer. It prevents radiation damage to healthy tissue.

\section{Safety, availability and affordability}

Most of the modern chemo drugs possess strong and harmful side effects, and are usually unaffordable by poor cancer patients due to their high cost, whereas Prophetic chemo is completely safe, natural, locally available, easily affordable and free from dangerous side effects. According to an article published in 2011 in the "American Journal of Chinese Medicine," multiple studies have confirmed there are no longterm side effects of taking black seed oil or thymoquinone orally on a regular basis.

\section{Cost of treatment}

Modern chemotherapy and radiotherapy cost from $\$ 5000-20,000$ or even more if treatment is done abroad, which most cancer patients cannot afford, whereas less than $\$ 5.00$ will be adequate for the cancer therapy using Prophetic chemo. This chemo is widely perceived as natural and safe. It is a divine gift of Allah to mankind. It is more affordable and easily obtainable. Raw material from which the Prophetic chemo is isolated is available in the country with little efforts. The great advantage of this chemo is that patients do not need to remain admitted in hospitals. The treatment can be done at home at almost zero cost. A Yemeni woman reports she was cured of stage 3 cancer after three months using prophetic chemo and honey [58-60].

\section{Duration of treatment}

Patients receiving Prophetic chemo mostly require about three to six months or so for complete recovery. The treatment can be done at home. On the other hand, patients receiving modern chemo need constant and continuous supervision of an oncologist in a hospital. Patients also require continuing the medication over a long period of one to three years or more.

\section{Mode of administration of the chemo drug}

Modern chemo drugs are given parenterally over a period of time, while Prophetic chemo can be given parenterally or orally without any difficulty. The seed can be crushed and taken with honey, added to a salad, swallowed with water or milk or taken as an ingredient of smashed potato. Prophetic chemo in right doses can be taken three times a day.

\section{Prophetic chemo prevents radiation damage to healthy tissues}

Radiotherapy causes radiation damage to healthy and vital body organs. On the other hand, reported research findings clearly show that Prophetic chemo could prevent radiation damage to healthy tissue if it is given before radiation therapy and is continued on a daily basis after each treatment [61].

\section{No approval from FDA or WHO needed for prescribing prophetic chemo}

Prescribing Prophetic chemo does not need approval from FDA or other world health bodies like WHO or any legislative body, because the raw material from which Prophetic chemo is obtained, has been used by millions of people for centuries throughout the globe as an edible safe healing herb. Modern chemo drugs are so potent that while killing cancer cells they also kill healthy cells, while research shows that Prophetic chemo kills human cancer cells while not being harmful to normal cells. The seeds are also very effective as remedies and have fewer or no unwanted side effects. According to an article published in 2011 in the "American Journal of Chinese Medicine," multiple studies have confirmed that there are no long-term side effects of taking Prophetic chemo orally on a regular basis. There are no known side effects of Prophetic chemo when taken in small quantities regularly [62-67].

The abstract says that acute and chronic toxicity studies have recently confirmed the safety of Nigella sativa oil and its most abundant active component, thymoquinone, particularly when given orally. Furthermore, recently El-Sayed I Salim, Shoji Fukushima carried out research on Chemo preventive potential of volatile oil from black cumin (Nigella sativa L.) seeds against rat colon carcinogenesis, where he indicated about no evidence of adverse effects of Nigella sativa. The findings of the research demonstrate that the volatile oil of Nigella sativa has the ability to inhibit colon carcinogenesis of rats in the post initiation stage, with no evident adverse side effects, and that the inhibition may be associated, in part, with suppression of cell proliferation in the colonic mucosa. The results were published in Nutr Cancer.

An abstract of a paper, "The Effect of Route of Administration in Thymoquinone Toxicity in Male and Female Rats by M. M. AbuKhader" published in the Indian J Pharm Sci. in 2012 says that the route of administration of thymoquinone could have an influence on thymoquinone toxicity outcome in both genders. It also says, peritoneal injection might be toxic to rats, and rats which received oral ingestion of thymoquinone showed only transient toxicity signs (not permanent). However, studies in laboratory animals have different mechanisms of action. But "thymoquinone" is not administered parenterally in humans. It is administered orally in combination with thymohydroquinone, dithymoquinone, thymol, carvacrol, nigellimineN-oxide, nigellicine, nigellidine, alpha-hederin and numerous other active ingredients present in the seed, which produce synergistic effects in cancer patients. So from this little finding we cannot precisely say that black seed containing thymquinone could be toxic to humans, because in case of cancer patients whole seed or black seed oil is recommended for cancer cure. Therefore, the number of positive evidences on the safety of thymoquinone is so huge that this transient single finding is ignorable or needs to be verified by subsequent studies [68].

In a 2014 study, Turkish researchers reported that many cancer patients treated with radiation therapy suffer severe side effects during and after their treatment. The study indicated that black seed oil could potentially be helpful to people receiving radiation treatment for cancer if added before the radiation treatment. In 2012 Indian scientists also 
confirmed that black seed oil helps patients exposed to harmful effects of radiation therapy from a study on a group of normal mice and another group of tumour bearing mice. The mice were given black seed extract before being exposed to the gamma radiation. Thus, the use of black seed oil before radiation treatment, and for 10 days afterward, protected the rats from some of the harmful effects of radiation [61].

\section{Prophetic medicine can cure a large number of human ailments}

The Prophet's statement, "Nigella sativa is a remedy (cure) for every disease except death" (Bukhari, Muslim and Ahmad), is found to be scientifically true. This amazing statement generated tremendous interest among the world's scientific community. Their question, how an unlettered man of the desert with any pen and paper can make such a wonderful statement on medical science?

The statement finally led the scientific community to carry out extensive phytochemical, pharmacological, toxicological and microbiological studies on black seed and its oil. Studies have been conducted using both intact animals and isolated tissues in various parts of the world for the treatment of a large number of diseases including diabetes, AIDS, high blood pressure, asthma, cancer etc. Recent scientific researches carried out at different countries of the world conclude that black seed was found effective in treating 129 different types of ailments including 17 different types of cancer (Hussain and Hussain, 2016). This further confirms that no one can claim the credit of knowing all these hidden facts of health \& wellness and diseases \& treatment as well as public health issues fourteen centuries ago, except a Prophet (PBUH), a chosen man from Allah (God). The important point is that Prophet Muhammad (PBUH) did not need to undertake any laboratory research to make such a statement. Indeed he was inspired to make such a great statement on medicine.

\section{Mechanisms of action of prophetic chemo}

Most alternative cancer treatments are much less expensive than surgery, radiation and chemotherapy. Prophetic chemo has been used to treat cancer for thousands of years. It has been used as traditional medicine for centuries. The Prophetic chemo is now found effective against many diseases like cancer, cardiovascular complications, diabetes, asthma, AIDS, high blood pressure, kidney disease etc. It is effective against cancer in blood system, lung, kidney, liver, prostate, breast, cervix, skin with much safety.

The molecular mechanisms behind its anticancer role are still not clearly understood. However, some studies showed that Prophetic chemo drug has antioxidant role and improves body's defense system. It is an immune system stimulant. It induces apoptosis, which means that it helps the body to systematically eliminate old cells, unneeded cells, and unhealthy cells (such as cancer cells) without releasing toxins into the body. It also controls the Akt pathway, which means it controls the process that manages cell survival for both normal and cancer cells.

Majdalawieh [68] reveal in the abstract of their research that thymoquinone (TQ), black seed's major active ingredient, has also been extensively studied and reported to possess potent anti-cancer properties. They provide a comprehensive review of the findings related to the anti-cancer activity of TQ, which focuses on analyzing experimental studies performed using different in vitro and in vivo models to identify the anti-proliferative, pro-apoptotic, anti-oxidant, cytotoxic, anti-metastatic, and NK-dependent cytotoxic effects exerted by TQ.
In addition, they have pinpointed the molecular mechanisms underlying these effects and the signal transduction pathways implicated by TQ. Their analysis shows that p53, NF- $\kappa B$, PPAR $\gamma$, STAT3, MAPK, and PI3K/AKT signaling pathways are among the most significant pathways through which TQ mediates its anticancer activity. Experimental findings and recent advances in the field highlight TQ as an effective therapeutic agent for the suppression of tumor development, growth and metastasis for a wide range of tumors.

\section{Effects of Black Seed or Prophetic Chemo on the Immune System}

\section{Black seed oil approved by us food and drug administration as an immune system stimulant}

In the spring of 1996 the U.S. Food and Drug Administration (FDA) granted a patent for the use of the extracts of Nigella sativa L., commonly known as the black seed or black cumin as an immune system stimulant. The patent was based on "a pharmaceutical composition containing an extract of the plant Nigella sativa for treating cancer, preventing the side effects of anticancer chemotherapy, and for increasing the immune functions in humans" [69].

Dr. Gary Null states, "Every time you take black cumin you are stimulating your immune system to fight on your behalf and increase natural killer cells." Thus, referring to its ability to improve the immune system and help treat even the most impossible invaders like cancer and HIV successfully. He further reveals black cumin does this by helping to stimulate the production of bone marrow and cells of the immune system. It increases the production of interferon, protects normal cells from the damaging effects of harmful invaders, helps destroy tumor cells and increases the number of antibody-producing $B$ cells within us. He also says that black cumin supports the entire body. Its immune-building properties and active compounds have been proven to help fight a never-ending list of diseases and autoimmune disorders via the boosting of the body's immune cell production, bone marrow and natural interferon. Even for people in the best state of health, consuming black cumin regularly has greatly increased their vitality and well-being! [70].

\section{Black seed extracts strengthen immune system}

Professor G. Rietmuller, Director of Institute for Immunology at the University of Munich reports that black seed extract works positively on the immune system and could be used as a bio-regulator. In Antiviral Agents Bulletin \#5,482,71, U.S. Patents Sections it was also mentioned that black seed increases immune function. Black Seed stimulates bone marrow and immune cells and raises the interferon production, protects normal cells against cell destroying effects of viruses, destroys tumor cells and raises the number of anti-bodies producing B cells [71]

\section{One gram of black seed oil twice daily increases the immunity} function

Scientifically it has been proved that immunity system is the only system that has the ability to combat diseases and produce cells that kill viruses. Researchers report quite frequently that Nigella sativa has the ability to strengthen and stabilize the body's immune system. Dr. Ahmad El -Qadi (Islamabad, Pakistan) and Dr. Usama Qandil (Florida, USA) found that taking 1 gram of black seed oil twice daily had an amazing effect of increasing the immunity function. This discovery is considered important to allow the use of black seed to increase the body's natural immunity for the treatment of cancer, AIDS and other 
diseases related to lack of immunity. He also found through research that black seed enhances analgesia (immune system) [72].

The role of black seed in increasing human immunity was not clear before 1986, when Dr. Qâdi and his colleagues started a series of researches in the United States. Afterwards, many researches were launched in various countries. Dr. Qâdi proved that the use of black seed strengthens immunity since the ratio of the $\mathrm{T}$ assitant lymph cells increased by an average of $72 \%$ compared to the restraining cells. Also, there was a considerable development in the activity of natural killer cells with an average of $74 \%$ [73].

The results of many modern researches supported the findings of Qadi. Amongst them are the results published by the International Immunity magazine in August 1995 about the effect of black seed on the outer lymph cells and the activity of white blood multi-nucleus cells. In September 2000, the International Immunity magazine also published a research on the effect of black seed oil in preventing cytomegalovirus on laboratory rats $[74,75]$.

\section{United States patents for inhibition of cancer cell growth and improvement of immune system}

It has been reported that black seed oil has received over 500 research studies since dramatically curing a show horse of asthma. The studies have verified many of its traditional remedies but also for serious modern diseases such as cancer and AIDS. This wonder herb is also powerful enough to be used at a practitioner's level with astounding versatility. It has now 5 separate patents in the US for the treatment of diabetes (US 6, 042, 834), inhibition of cancer cell growth (US 5, 653,981), improvement of the immune system (US 5,482,711), viral infection (US 6, 841,174) and psoriasis (US 6, 531,164) [76].

\section{Global war on cancer}

Recently John Thomas wrote a book titled; We lost the war on cancer - Review of alternative cancer therapies. The book has been published as kindle edition. Amazon.com rates the book as one of the best books of the month of April 2016.

\section{In his book John Thomas writes:}

Although there have been various alternative cancer therapies that have been proven effective, but that are not approved by the FDA, because pharmaceutical companies are opposed to the development of all forms of cancer treatment. They work together with the US FDA and various US government cancer research funding agencies to prevent new treatments from being approved for use by physicians.

He further writes, "Pharmaceutical companies are in the business of treating cancer, not curing it. \$Billion Cancer industry depends on NO Cures! He adds that the effective alternative cancer cures are a threat to modern medicine."

Thomas further reveals through surveys in part II of his book that there are various alternative cancer therapies that have been proven effective, but that are not approved by the FDA [77].

\section{Prophetic chemo can effectively cure most types of cancers}

The published work for the cure of various types of cancers using Prophetic chemo is very rich. Some are cited below. Liver cancer [78], brain cancer, skin cancer, pancreatic cancer [79-81], cervical cancer $[82,83]$ and [84], breast cancer [85-88], and [89] bone cancer [90], gastric cancer, prostate cancer, stomach cancer, colon cancer, esophagus cancer, kidney cancer, melanoma skin cancer, lymphoma, blood cancer, hepatic cancer, renal cancer, lung cancer, colorectal cancer, fibrosarcoma [91-100].

Hassan a practicing medical doctor in Surrey, England in a study examined a highly malignant strain of squamous cell carcinoma, which was taken from various patients with oral cancer. He says this particular cancer type also causes many other cancers of the head and neck.

\section{Breast cancer and Nigella sativa}

In a copyrighted article for Nigella sativa.com an anonymous online writer after citing several research findings reported that black cumin is breast cancer's worse enemy. He further reported, "Scientists have discovered that black seeds have anti-cancer (tumor) properties. It doesn't just prevent or treat cancer, but in many cases totally destroys (apoptosis) the cancer cells".

Recently extract of Nigella sativa oil (Black Seed Oil, BSO) and the bioactive compound Thymoquinone (TQ) have been have investigated and found effective against breast cancer in female rats. Researchers mentioned that Thymoquinone (TQ) is now known to be the primary active constituent of black cumin seed oil (BCS oil) responsible for its medicinal effects and also showing promise for treatment of cancer [101].

Researchers have studied the effects of Thymoquinone (TQ) and Black Seed Oil (BSO) on tumor markers (MDA, LDH, ALP and AST), histopathological alterations and the regulation of several genes (Brca1, Brca2, Id-1 and P53 mutation) related to breast cancer in female rats induced by 7,12-dimethylbenz[a]anthracene (DMBA) treatment. It was found that TQ and then BSO reduced the rate of tumor markers (levels of MDA and LDH as well as ALP and AST activities), inhibited the histopathological alterations and decreased the expression of the Brca1, Brca2, Id-1 and P53 mutations in mammary tissues of female rats induced by DMBA treatment. The results suggest that TQ and BSO exert a protective effect against breast carcinogens. The antioxidant property of TQ and BSO oil is mediated by their actions and other underlying mechanisms.

In 2003, at the Jackson State University, USA, doctors and researchers interested to investigate why Nigella sativa had been used for such a long time for the treatment of so many acute ailments and studied its effectiveness in cancer prevention. They exposed breast cancer cells to Nigella sativa extracts, and the cells were inactivated. Doctors concluded that it had promising results in the field of prevention and treatment of breast cancer (Farah and Begum, 2003).

\section{Treatment of breast cancer using prophetic chemo}

In a study it has been proven that the extracts of Nigella sativa, aqueous and alcoholic extracts, with the combination of $\mathrm{H}_{2} \mathrm{O}_{2}$ are effective against MCF-7 cells (breast cancer cell line). These extracts inactivate the MCF-7 cells and affect their survivability. That's why Nigella sativa provides a promising treatment for breast cancer. In another study, the survivability of MCF-7 cells was measured. The MCF-7 cells were exposed to the aqueous and alcoholic extracts of Nigella sativa. Results revealed that the extracts alone, without any combination or concentration, are effective against this disease.

Apart from the above, a well-researched study from professional scientists proved that TQ induces p38 phosphorylation and ROS production in breast cancer cells. These inductions by Thymoquinone are indeed responsible for its anti-proliferative and pro-apoptotic effect. 
They prevent the spreads of the cell, especially cancerous and malignant cells, into surrounding tissues. Researchers opined that the effects of bioactive TQ have been responsible against cancer. That's why it is famous as one of the most important compounds against cancer. It is also reported that there is another extract of Nigella sativa, supercritical$\mathrm{CO}_{2}$. It also possesses anti-cancer activity against MCF-7 breast cancer cells. Researchers say that though, it is a quite recent study, but the results revealed that the supercritical- $\mathrm{CO}_{2}$ extract of Nigella sativa can be used to treat breast cancer, because Thymoquinone (TQ) owns antiproliferative activity.

The bioactive compound Thymoquinone (TQ) has also been recently investigated against breast cancer. Scientists carefully assessed the cell responses after TQ treatment. They discovered that the Thymoquinone is an anti-tumor compound, which possesses anti-neoplastic activity against multifarious tumors. Furthermore, the mechanism of action of Thymoquinone (TQ) also leads to apoptosis in cancer cells. Apoptosis is a programmed cell death program. The death of the cancer, injured, or damaged cell occurs as a normal and controlled part of an organism's development.

Nigella sativa, in combination with melatonin and retinoic acid reduced the carcinogenic effects of DMBA (7, 12-di-methylbenz(a) anthracene) in mammary carcinoma of rats. Terpene-terminated 6-alkyl residues of TQ were tested in MCF-7/Topo breast carcinoma. They found the derivatives inducing cell death by apoptosis. Numerous studies have reported that thymoquinone or black cumin seed extract have anti-cancer activity in animal models of triple negative (ER-/ PR-/HER2-) breast cancer, as well as in ER-/PR-/HER2- breast cancer cells. Thymoquinone has anti-proliferative effects and promotes programmed cell death. The picture is less clear in hormone receptor positive $(\mathrm{ER}+/ \mathrm{PR}+)$ breast cancer-some studies have reported only a modest reduction in growth or proliferation as a result of treatment with thymoquinone [102-105].

Thymoquinone has anti-proliferative effects and promotes programmed cell death. The picture is less clear in hormone receptor positive $(\mathrm{ER}+/ \mathrm{PR}+)$ breast cancer-some studies have reported only a modest reduction in growth or proliferation as a result of treatment with thymoquinone.

Furthermore, the antitumor activities of Thymoquinone (TQ), isolated from Nigella sativa oil, were further investigated in breast carcinoma in vitro and in vivo. The results demonstrated that the anti-proliferative and pro-apoptotic effects of TQ in breast cancer are mediated through $\mathrm{p} 38$ phosphorylation via ROS generation.

Aqueous and alcohol extracts of $N$. sativa were found to be effective in vitro in inactivating MCF-7 breast cancer cells. A paper on the Effect of Nigella sativa and oxidative stress on the survival pattern of MCF-7 breast cancer cells was published by Farah and Begum in 2003. It was found that $\mathrm{N}$. sativa alone or in combination with oxidative stress were found to be effective in vitro in inactivating MCF-7 breast cancer cells, unveiling opportunities for promising results in the field of prevention and treatment of cancer.

\section{Malaysian scientists confirm black seeds inhibit breast cancer}

A study, conducted in 2013 in Malaysia, addressed the anti-cancer efficiency of thymoquinone when it was used for long-term treatment of human breast cancer cell lines in the laboratory. Thymoquinone showed a sustained ability to inhibit breast cancer cell proliferation with long-term treatment. The length of inhibition was determined by the size of the thymoquinone dose. Larger doses produced greater inhibition.

\section{Black cumin increases the effectiveness of many types of breast cancer treatment}

In a study using tumor-bearing mice it has been reported that that the combination of thymoquinone plus adriamycin suppressed tumor growth more than treatment with adriamycin alone. Thymoquinone also potentates the cytotoxic effects of tamoxifen in ER+/PR+ breast cancer. In addition, thymoquinone has been shown to radiosensitize $\mathrm{ER}+/ \mathrm{PR}+$ breast cancer cells, thereby increasing the treatment effects of radiotherapy.

Recently anti-cancer activity of Thymoquinone in breast cancer cell has been investigated by Woo CC at the Department of Pharmacology, Yong Loo Lin School of Medicine, National University of Singapore, Singapore. It was found that TQ exerted strong anti-proliferative effect in breast cancer cells and, when combined with doxorubicin and 5-fluorouracil, increased cytotoxicity. The researchers suggested that TQ may have potential implication in breast cancer prevention and treatment and showed for the first time that the anti-tumor effect of TQ may also be mediated through modulation of the PPAR- $\gamma$ activation pathway [106-108].

After reviewing hundreds of research results carried out in different parts of the globe, we humbly conclude the section by saying that Nigella sativa shows promising positive results in treating breast cancer. It doesn't matter in which stage of breast cancer one is struggling with, the bioactive compound TQ and different aqueous, and alcoholic extracts of the seeds, create an unknown mechanism which treats breast cancer quickly.

\section{Results and Discussion}

After reviewing nearly 500 scientific research abstracts on the successful use of black seed oil and thymoquinone with various types of cancers, and despite recommendations made by many global scientists, we wonder why there have been very little clinical trials. However, despite several decades of very positive research on using black seed oil against cancer, researchers have rarely advanced their work into human clinical testing, even though the benefits are strong, convincing and the risks of negative side effects are extremely small. Furthermore, despite tremendous success with using black seed oil with animals there isn't much published research pointing to systematic human clinical trials.

Since black seed and its oil possess significant anti-cancer properties that have been shown by numerous researches discussed above and since it has been proven to be non-toxic to healthy human cells, then why are the scientists still doing laboratory research? Why are the scientific communities delaying in undertaking systematic and target-oriented human trials?" What is the reason for the delay of conducting large scale clinical trials with Thymoquinone (Prophetic chemo) using human volunteers? However, whatever the reasons might be, the developed countries need to demonstrate commitment to make further clinical research on black seed or thymoquinone to establish its efficacy in humans. Global scientists should start think seriously. Even a president's family member can be attacked with cancer and eventually die without having access to appropriate treatment.

It is imperative to know that Prophet Muhammad (PBUH) did not attend any school, college or university for learning medical science. He did not even go to any Madrassa (religious school) for acquiring knowledge. No one can claim that he taught Muhammad (PBUH). 
In fact Allah Himself was his only Educator. He taught him through Angel Gabriel (as). He trained him as per His Own divine plan. So like his thousands of statements on various religious and socio-economic matters, duties and obligations, war and peace, civilizations and culture, his specific statements on healing are also based on divine inspirations, because he made the statements at a time when there was no chemistry, no pharmacy or medical science. Moreover, concerning his utterances and statements, Allah (God) cautioned him in strong terms. Allah, the Most High said,

"And if Muhammad had made up about Us some [false] sayings, We would have seized him by the right hand; then We would have cut from him the aorta" (Quran, 69: 44-46).

\section{Prophetic chemo is the divine remedy}

Today modern science reveals through numerous researches that black seed cures a large number of diseases. This demonstrates the authenticity of the Prophet's statement. In deed black seed is a divine cure, not man-made cure. Although there were more than 400 herbs in use before Prophet Muhammad (PBUH), and recorded in the herbals of Galen and Hippocrates, black seed was not one of the most popular remedies of that time. Since black seed is now considered "a remedy of the Prophet (PBUH), its usage and popularity have increased significantly. Today due to findings of modern research, many modern scientists classify it as: all-in-one therapy, cure-all herb, a universal remedy and a magical herb. Some call it medicinal dynamite. Black seed has proved to be a genuine universal remedy and it is an extraordinary herb which can be the primary health-bolstering agent of the millennium.

For people with cancer, discovery of Prophetic chemo could be great news to both the Muslim and non-Muslim world, but to the pharmaceutical industry, this would be extremely bad news for profitability, because Prophetic chemo is not a "new drug" and it cannot be patented. Thomas [109] further reveals that the pharma industry cannot monopolize in chemo drug business. The great fear of the pharmaceutical industry is that a non-patentable and inexpensive cure for cancer might prevent them out of drug business. These organizations exist to turn a profit from cancer treatment, which is measured in billions of dollars every year. They are in the business of treating cancer, not curing it.

\section{Information available in this article could be a break- thorough in global cancer research}

So although most alternative cancer treatments are much cheaper than surgery, radiation, and chemo, and are also more effective having no unwanted side effects, the pharmaceutical industries are not interested in introducing and promoting alternative cancer treatments due to obvious reasons. So if we wish to win the war on cancer we must use Prophetic chemo. We sincerely opine that the information available in this article can be considered as treasure of knowledge. It could be a break-thorough in global cancer research.

\section{Cancer is curable}

Cancer is a fatal and disastrous disease, but not incurable. The Prophet (PBUH) said, "Allah (God) did not send down a disease without having sent down its cure" (Bukhari and Muslim). So, since cancer is a disease, it is curable if right medicine is taken at the right time. In another Prophetic tradition narrated by Zaid Ibn Aslam (ra), The Prophet (PBUH) said, ".....................He Who has created disease has also created its remedy" (Za'adul Ma'ad and Mu'atta). The Prophet
(PBUH) further said, as narrated by Usama ibn Sharik (ra), "I was with the Prophet (PBUH) when some Arabs (Bedouins) came to him and said: O Messenger of Allah, should we seek medicine? He said: Yes, O servants of Allah, seek medicine, for Allah has created a cure for every disease that He has created, with the exception of one illness. They asked: What is that? He responded: Old age" (Recorded by Ahmad, at-Tirmidhi, Abu Dâwood and Ibn Mâjah).

From the first two Prophetic traditions we understand that medicines for all diseases are in place. Allah has created the remedies first, then the diseases. But all medicines are yet to be discovered by scientists. So there is room for continued research. We must continue to make research to look for appropriate remedies for new ailments. From the second Prophetic tradition we come to know cancer is curable, but aging is not. Some scientists say that aging is not a disease. But we do not agree with them. This is because, according to the Prophet (PBUH), it is a disease but untreatable, incurable. Symptoms of old ages can be treated to some extent, but aging cannot be treated. One can slow down the aging process with the help of some antioxidants, good quality foods, exercise, regular walking etc. but none can prevent it. One can change the grey colour of his hair black with a dye to look young, but he cannot recover the strength and energy he had while he was young.

\section{Allah is the healer, and the doctors and the medicines are the means of healing}

It is the discretion of the patients and their relatives to take the patients to the most competent, most experienced and highly skilled physician of the most sophisticated hospital of the world, but the physician cannot give any guarantee for the healing. Healing is not in the hands of physicians or men. It is in the hands of Allah. If Allah does not wish healing, the patient will not be healed, no matter the extent of medical services offered by the physicians.

The Islamic concept of healing is that Allah is the Healer, and the doctors and the medicines are the means of healing. According to this concept, a physician examines a patient, diagnoses an ailment and prescribes medicine(s); a pharmacist prepares the medicines and dispenses them to the patient. Ultimately, it is Allah, who heals the ailment through the medicine. According to another Prophetic narration, Allah is the physician and doctor is the friend of the Prophet (PBUH) (Musnade Ahmad). Thus, pharmacy and medicine, disease and treatment, and patient and physician are all interrelated in the process of healing, which is done by Allah in Whom full trust should be placed. In support of this in the tongue of Prophet Ibrahim (AS) the Qur'an says:

"And when I am ill, it is He Who heals (cures) me". (Quran, AshShuara 26:80) [110].

\section{A note to the readers}

Let us ask a question, those who go to developed foreign countries for better treatment, do they all return home after cure? Many a time dead bodies return home, not healthy persons after getting well. A good number of political leaders of our country very recently went to several prestigious hospitals in Singapore and Bangkok for better treatment, but unfortunately their dead bodies only returned home. On the other hand one cannot apply any force for the healing. Let us give another example. Suppose the President of a nation is sick due to high fever. The army is under his command. Can he call the army with tanks and machine guns to fight with fever? No, not at all possible. 


\section{A note to the respected scientists}

The most important point we want to focus is that we must always firmly believe that death is inevitable. Any time it might visit us without any notice, whether we are young or old, whether we are ready to welcome it or not. No one knows when, how and where one is going to die. God has preserved everything in an open Book (available with Him only) (Qur'an 36:12) [111]. Therefore, if one is destined by God to die through sickness like cancer, none can prevent it. No board of doctors can save him. At the moment of death doctors and relatives continue looking at the dying person helplessly. At the point of death God asks man to restore to the dying person his soul if he is able to do so. He says, can't you see Me? I am very near to you. The Qur'an says, "Then why, when the soul at death reaches the throat, and you are at that time looking on, and Our angels are nearer to him than you, but you do not see. Then why do you not, if you are not to be recompensed, bring it back, if you should be truthful? (Qur'an, Al-Waqiah 56: 83-85) [112]. So, if there is a remedy that can cure all ailments except death, then why shouldn't we accept it with reason and introduce it in the public health sector as the best medicine for the treatment of cancer.

\section{A note to the honorable scientists}

It is not very important to know who invented, discovered or recommended a particular remedy, but healing is important. The gift of modern science invented or discovered by any one should be available and accessible to anyone who deserves or is in need of. Health is wealth and sickness is a global problem. It is the desire of every one of us to remain safe free from illness to fulfil our brief mission on earth. After that time whether we like it or not, we have to return to Allah (God), the Lord of the world. So no discrimination should be made in case of healing. However, one must remember that divine remedy is the best. It is also safer, cheaper and most effective than man-made remedies, and modern medical science has proved it through numerous researches [113].

\section{A note to the dear learned physicians}

It is important to mention it here that using Prophetic chemo does not need any prescription from a physician or approval from FDA or WHO. Prophetic chemo is obtained from a herb which has been proved to be very safe throughout centuries. It is a pity that despite having thousands of scientific researches on the efficacy and beneficial activities of Nigella sativa in humans, no university or govt. research organization has undertaken any systematic large scale clinical trial program using human volunteers. May we ask, what is the success rate of modern chemo? The answer is very low, almost zero. I wrote to the chief oncology consultants of several cancer hospitals in Dhaka Bangladesh to know the success rate of modern chemotherapy, but they didn't respond even after sending several friendly reminders. Oncology hospitals are not interested to know the fate of their cancer patients who earlier received treatment upon admission. They are also not interested to find out when their cancer patients, who after being discharged from the hospital, died. They also do not maintain any survery record of their success rate of chemotherapy. So, it is not unreasonable to say that the success rate of modern chemo is almost zero [114].

Dear oncologists, Over the past 100 years, the American Cancer Society has been working relentlessly to end cancer. The ACS's recent slogan is "Cancer affects everyone. Let's change it." But despite relentless efforts by the global scientists the situation still remains unchanged and seems increasing at an alarming rate. That is why we feel that man-made cure is not adequate to fully eradicate this disease from the face of the earth. The disease 'cancer' has not been created by any man or physician. It has been created by God, and it is He who also sent down the remedy before the disease was created. So His remedy shall be the best remedy. Therefore, we think divine remedies should be allowed to play a vital role in reversing the trend. If we can face the medical challenges of today with an open and broad mind free from bias, preconceived notions and ideas we shall soon see a brighter world free from cancer, diabetes, AIDS and other dangerous killer diseases. The world belongs to all of us. Let's put our hands together and utilize the God-gifted talents and intellect to change the world. Our collective wisdom is essential to cure cancer [115-120].

\section{Conclusion}

In view of the reported side effects of modern chemo drugs we strongly recommend that 'thymoquinone' from black seed can be considered as the cheapest, safest and most effective alternative to modern chemotherapy for the treatment and cure of all forms of cancer. Global scenario dictates us that there is an urgent need for introducing alternative cancer therapies in the public health sector. In addition, cost of modern chemo drugs and radiotherapy is very expensive, which poor patients and ordinary citizens cannot afford. Out of the alternative therapies we recommend black seed therapy prescribed by the Prophet Muhammad (PBUH) for all diseases, of which cancer is one. Therefore, it is the demand of the time that implementation of divine cure for this fatal disease should be done without any delay $[121,122]$.

In view of the above global scenario, we urge the medical scientists and oncologists to stop prescribing modern chemo drugs for the treatment of cancer patients. Don't rob hundreds of thousands of dollars from poor patients in the name of treating cancer. Don't make cancer patients die before their normal death. Inform your patients about all the strong, severe and harmful side effects and the fatal consequences of receiving modern chemo. Tell them that modern chemotherapy destroys the fertility of both men and women. It causes early menopause. In conclusion, we would like to urge the developed countries of the world to consider Prophetic chemotherapy for conducting systematic and organized clinical trial without wasting any time, and if successful, which we are sure they will, WHO and FDA should approve it as commercial drug without any patent right for the interest of health of the humankind. We hope using this divine remedy the large number of cancer patients in various countries of the world will get rid of the disastrous disease at no cost, and live happily and peacefully for the rest of their life.

\section{References}

1. Hussain D, Hussain M (2016) Nigella sativa (black seed) is an effective herbal remedy for every disease except death - A prophetic statement which modern scientists confirm unanimously: A review- Advancement in Medicinal Plant Research 4: 27-57

2. Holy Qur'an, Chapter An-Najm 53: 3.

3. Holy Qur'an, Chapter Al-Haqqah 69: 44-46.

4. Dâwood A, Chapter Treatment Hadith No. 3815.

5. Koehnlechner (1987) Plants that fight cancer. Kintzios SE, Barberaki MG (eds), Science 2: 1.

6. Konstantakou BE (1989) Chemotherapy. Bera Medical Arts, Athens.

7. American Cancer Society [https://www.cancer.org/...side-effects/... chemotherapy/chemotherapy-side-effects.html].

8. Hussain MM (2014) Medicine and pharmacy in the prophetic traditions". International Islamic Publishing House, Riyadh, Saudi Arabia. 
Citation: Deena HAS, Hussain MM (2018) Prophetic Chemo Is the Safest, Cheapest and Most Effective Alternative to Modern Chemotherapy for the Cure of all Forms of Cancers - A Review. J Cancer Sci Ther 10: 090-104. doi: 10.4172/1948-5956.1000525

9. Kintzios SE, Barberaki MG (2004) Plants that fight cancer. CRC Press LLC. USA.

10. Salomi NJ, Nair SC, Jayawardhanan KK, Varghese CD, Panikkar KR (1992) Antitumour principles from Nigella sativa seeds, Cancer Lett 63: 41-46.

11. Salomi MJ, Nair SC, Panikkar KR (1991) Inhibitory effects of Nigella sativa and saffron (Crocus sativus) on chemical carcinogenesis in mice. Nutr Cancer 16: $67-72$.

12. Worthen DR, Ghosheh, OA, Crooks PA (1998) The in vitro anti-tumor activity of some crude and purified components of black seed, Nigella sativa L. Anticancer Res 18: 1527-1532.

13. Badary OA, Taha RA, Gamal El-Din AM, Abdel-Wahab MH (2003) Thymoquinone is a potent superoxide anion scavenger. Drug Chem Toxicol 26: 87-98.

14. Bourgou S, Ksouri R, Bellila A, Skandrani I, Falleh H, et al. (2008) Phenolic composition and biological activities of Tunisian Nigella sativa L. shoots and roots. C R Biol 331: 48-55.

15. Khader M, Bresgen N, Eckl PM (2010) Antimutagenic effects of ethanolic extracts from selected Palestinian medicinal plants. J Ethnopharmacol 127: 319-324.

16. Al-Ali A, Alkhawajah AA, Randhawa MA, Shaikh NA (2008) Oral and intraperitoneal LD50 of thymoquinone, an active principle of Nigella sativa, in mice and rats. J Ayub Med Coll Abbottabad 20: 252-257.

17. Ali BH, Blunden G (2003) Pharmacological and toxicological properties of Nigella sativa. Phytother Res 17: 299-305.

18. Anderson K (2014) [http://www.cancercenter.com/discussions/blog/do-blackcumin-seeds-hold-the-cure-to-colon-cancer/].

19. 19. Shoieb AM, Elgayyar M, Dudrick PS, Bell JL, Tithof PK (2003) In vitro inhibition of growth and induction of apoptosis in cancer cell lines by thymoquinone. Int J Oncol 22: 107-113.

20. Gali-Muhtasib H, Diab-Assaf M, Boltze C, Al-Hmaira J, Hartig R, et al. (2004) Thymoquinone extracted from black seed triggers apoptotic cell death in human colorectal cancer cells via a p53-dependent mechanism. Int J Oncol 25 857-866

21. Roepke M, Diestel A, Bajbouj K, Walluscheck D, Schonfeld P, et al. (2007) Lack of p53 augments thymoquinone-induced apoptosis and caspase activation in human osteosarcoma cells. Cancer Biol Ther 6: 160-169.

22. Badary OA, Gamal EI-Din AM (2001) Inhibitory effects of thymoquinone against 20-methylcholanthrene-induced fibrosarcoma tumorigenesis. Cancer Detect Prev 25: 362-368.

23. Awad EM (2005) In vitro decreases of the fibrinolytic potential of cultured human fibrosarcoma cell line, HT1080, by Nigella sativa oil. Phytomedicine 12 : 100-107

24. Kaseb AO, Chinnakannu K, Chen D, Sivanandam A, Tejwani S, et al. (2007) Androgen receptor and E2F-1 targeted thymoquinone therapy for hormonerefractory prostate cancer, Cancer Res 67: 7782-7788.

25. El-Mahdy MA, Zhu Q, Wang QE, Wani G, Wani AA (2005) Thymoquinone induces apoptosis through activation of caspase-8 and mitochondrial events in p53-null myeloblastic leukemia HL-60 cells. Int J Cancer 117: 409-417.

26. Banerjee S, Parasramka M, Sarker FH, Mohammad RM (2012) Molecular insight and preclinical perspective of thymoquinone' as chemopreventive agent and therapeutic adjunct in cancer. Nutrition, Diet and Cancer pp 83-107.

27. Thomas J (2014) We lost the war on cancer. Brian Shilhavy (Editor), Review of alternative cancer therapies, Kindle edition, Sophia Media, LLC, USA. p: 49.

28. Black cumin-The ultimate life elixir [https://www.activationproducts.com/article/ black-cumin/].

29. Europacolon Global Health Education Partnership [http://www.europacolon com/news.php?Action=News\&News_ID=1026]

30. 30. Li F, Rajendran P, Sethi G (2010) Thymoquinone inhibits proliferation, induces apoptosis and chemo-sensitizes human multiple myeloma cells through suppression of signal transducer and activator of transcription 3 activation pathway, Br J Pharmacol 161: 541-554.

31. Disease does not stand a chance against black cumin. [http://preventdisease. com/news/14/112614_disease-does-not-stand-a-chance-against-black-cumin shtml].

32. What is black cumin and why is it so powerful?. [http://www.bodyandmind co.za/m.info_pgs.php?action=info_page\&id=2729\&page=Black\%20Cumin].

33. Black Seed Oil \& Cancer [http://www.livestrong.com/article/502091-blackseed-oil-cancer/].

34. Black Seed Oil (Nigella sativa) and its thymoquinone are effective against breast cancer and other malignancies. [http://holisticoncologymovie.com/?p=770].

35. Do black cumin seeds hold the cure to colon cancer? [http://www.cancercenter com/discussions/blog/do-black-cumin-seeds-hold-the-cure-to-colon-cancer/].

36. Medenica R, Janssens J, Tarasenko A, Lazovic G, Corbitt W, et al. (1997) Black seed oil has been shown to fight cancer: Anti-angiogenic activity of Nigella sativa plant extract in cancer therapy. Proc Annu Meet Am Assoc Cancer Res 38: A1377.

37. Medical Plants Magazine, February, 1995

38. Randhawa MA, Alghamdi MS (2011) Anticancer activity of Nigella sativa (black seed) - a review. Am J Chin Med 39: 1075-1091.

39. Black Seed Oil (Nigella Sativa) and its disease preventing effects. [http:// www.healthymuslim.com/articles/mdhpn-black-seed-oil-nigella-sativa-and-itsdisease-preventing-effects.cfm]

40. Black Seeds Benefits. [https://archive.org/stream/BlackSeedsBenefits/BlackSeeds-Benefits_djvu.txt].

41. Banerjee S, Padhye S, Azmi A, Wang Z, Philip PA, et al. (2010) Review on molecular and therapeutic potential of thymoquinone in cancer. Nutr Cancer 62 : 938-946.

42. Abukhader MM (2013) Thymoquinone in the clinical treatment of cancer: Fact or fiction?" Pharmacogn Rev 7: 117-120.

43. Shuid AN, Mohamed N, Mohamed IN, Othman F, Suhaimi F, et al. (2012) Nigella sativa: A potential antiosteoporotic agent, Evidence-based Complementary \& Alternative Medicine (eCAM) Article ID 696230.

44. Black Seed Oil \& Cancer [http://www.livestrong.com/article/502091-blackseed-oil-cancer/].

45. Kahului HI [http://chiropracticmaui.com/disease-does-not-stand-a-chanceagainst-black-cumin/].

46. GreenMedInfo January 3, 2013

47. The Power of Nigella sativa (Black Seed) [http://nuverus.com/u/2/country/usa/ web/blackseed-nigella-sativa.php]

48. Schleicher P, ґSaleh M (2000) Black cumin: The magical Egyptian herb for allergies, asthma, and immune disorders. Publisher: Healing Arts Press, NY, USA.

49. http://www.beautifulislam.net/black seed/black_seed_benefits_p.html

50. http://www.livestrong.com/article/502091-black-seed-oil-cancer/

51. Khan MA, Chen HC, Tania M, Zhang DZ (2011) Anticancer activities of Nigella sativa (black cumin). Afr J Tradit Complement Altern Med 8: 226-232.

52. Hassan A (2014) Black seed oil extract causes oral cancer cells to self-destruct. Green Med Info LLC

53. Ji S (2014) Research finds black seed therapeutic for aging women GreenMedInfo LLC. [http://wondrousroots.org/wp-content/uploads/2016/12/ Research-Finds-Black-Seed-Therapeutic-For-Aging-Women.pdf]

54. 54. Majdalawieh AF, Fayyad MW, Nasrallah GK (2017) Anti-cancer properties and mechanisms of action of thymoquinone, the major active ingredient of Nigella sativa. Crit Rev Food Sci Nutr 57: 3911-3928.

55. Nigella sativa oil: Another hidden miracle [http://womansvibe.com/nigellasativa-oil-another-hidden-miracle/].

56. Black cumin-A life elixir for all illness except death. [http://www thealternativedaily.com/black-cumin/].

57. Hassan MI, Mabrouk GM, Shehata HH, Aboelhussein MM (2012) Antineoplastic effects of bee honey and Nigella sativa on hepatocellular carcinoma cells. Integr Cancer Ther 11: 354-363.

58. http.//www.naturalnews.com/027731_cancer_survivors_natural_remedies.htm 
Citation: Deena HAS, Hussain MM (2018) Prophetic Chemo Is the Safest, Cheapest and Most Effective Alternative to Modern Chemotherapy for the Cure of all Forms of Cancers - A Review. J Cancer Sci Ther 10: 090-104. doi: 10.4172/1948-5956.1000525

59. Black seeds- cancer. The cost of cancer - Part V - Nigella sativa - Black cumin - black seeds [http://blackseeds1.blogspot.com/2012/09/the-cost-of-cancerpart-v-nigella.html].

60. Medenica R, Janssens J, Tarasenko A, Lazovic G, Corbitt W, et al. (1997) Black seed oil has been shown to fight cancer: Anti-angiogenic activity of Nigella sativa plant extract in cancer therapy. International Immuno-Biology Research Laboratory.

61. Cikman O, Ozkan A, Aras AB, Soylemez O, Alkis H, et al. (2014) Radioprotective effects of Nigella sativa oil against oxidative stress in liver tissue of rats exposed to total head irradiation. J Invest Surg 27: 262-266.

62. Ahmad, Chapter, Musnade Abu Hurayrah (ra), Hadith Nos. 7557, 9467, 10048.

63. Tirmidhi, Chapter Treatment, Hadith No. 1988

64. Ibn Mâjah, Chapter Treatment, Hadith No. 3447; 3436

65. Mustadraq, Chapter Treatment, Hadith No. 7427.

66. Randhawa MA, Al-Ghamdi MS (2011) Anticancer activity of Nigella sativa (Black seed)- A Review. Am J Chin Med 39: 1075.

67. Majdalawieh AF, Fayyad MW (2016) Recent advances on the anti-cancer properties of Nigella sativa, a widely used food additive, J Ayurveda Integr Med 7: $173-180$.

68. http//www.islamicbulletin.org/newsletters/issue

69. Black Cumin-The Ultimate Life Elixir [https://www.activationproducts.com/ article/black-cumin/].

70. https://archive.org/stream/BlackSeedsBenefits/Black-Seeds-Benefits_djvu.txt

71. Black Seeds "A cure for every disease except death." (Sahih Bukhari) [https:// www.missionislam.com/health/blackseed.html].

72. https://www.thetruthmag.com/index.php/features/science-and-space/558scientific-signs-in-the-quran-and-sunnah-part-2

73. International Immunity Magazine, August 1995

74. http://turntoislam.com/community/threads/alternative-medicine.83152/

75. https://www.prlog.org/10265287-black-cumin-oil-the-wonder-ancient-herbalremedy-with-over-6-drug-patents-in-the-us-and-uk.html)

76. https://healthimpactnews.com/2014/black-seed-oil-cures-many-cancersaccording-to-numerous-studies/

77. Nagi MN, Almakki HA (2009) Thymoquinone supplementation induces quinone reductase and glutathione transferase in mice liver: possible role in protection against chemical carcinogenesis and toxicity. Phytother Res 23: 1295-1298.

78. Mohamed A, Sapuan SM, Ahmad MH, Hamouda AM, Baharudin BH (2010) Modeling technology transfer for petroleum industry in Libya: An overview. Sci Res Essays 5: 130-147.

79. Banerjee S, Wang Z, Mohammad M, Sarkar FH, Mohammad RM (2008) Efficacy of selected natural products as therapeutic agents against cancer. J Nat Prod 71: 492-496.

80. Chehl N, Chipitsyna G, Gong Q, Yeo CJ, Arafat HA (2009) Anti-inflammatory effects of the Nigella sativa seed extract, thymoquinone, in pancreatic cancer cells. HPB (Oxford) 11: 373-381.

81. Banerjee S, Kaseb AO, Wang Z, Kong D, Mohammad M, et al. (2009) Antitumor activity of gemcitabine and oxaliplatin is augmented by thymoquinone in pancreatic cancer. Cancer Res 69: 5575-5583.

82. Shafi G, Munshi A, Hasan TN, Alshatwi AA, Jyothy A, et al. (2009) Induction of apoptosis in HeLa cells by chloroform fraction of seed extracts of Nigella sativa. Cancer Cell Int 9: 29-36.

83. Effenberger K, Breyer S, Schobert R (2010) Terpene conjugates of the Nigella sativa seed-oil constituent thymoquinone with enhanced efficacy in cancer cells. Chem Biodivers 7: 129-139.

84. Alenzi FQ, El-Bolkiny YS, Salem ML (2010) Protective effects of Nigella sativa oil and thymoquinone against toxicity induced by the anticancer drug cyclophosphamide. Br J Biomed Sci 67: 20-28.

85. Farah IO, Begum RA (2003) Effect of Nigella sativa (N. sativa L.) and oxidative stress on the survival pattern of MCF-7 breast cancer cells. Biomed Sci Instrum 39: 359-364.
86. El-Aziz MA, Hassan HA, Mohamed MH, Meki AR, Abdel-Ghaffar SK, et al. (2005) The biochemical and morphological alterations following administration of melatonin, retinoic acid and Nigella sativa in mammary carcinoma: an animal model. Int J Exp Pathol 86: 383-396.

87. Majdalawieh AF, Fayyad MW (2016) Recent advances on the anti-cance properties of Nigella sativa, a widely used food additive. J Ayurveda Integr Med 7: 173-180.

88. Majdalawieh AF, Fayyad MW, Nasrallah GK (2017) Anti-cancer properties and mechanisms of action of thymoquinone, the major active ingredient of Nigella sativa. Crit Rev Food Sci Nutr 57: 3911-3928.

89. Motaghed M, Al-Hassan FM, Hamid SS (2013) Cellular responses with thymoquinone treatment in human breast cancer cell line MCF-7. Pharmacognosy Res 5: 200-206.

90. Woo CC, Kumar AP, Sethi G, Tan KH (2012) Thymoquinone: potential cure for inflammatory disorders and cancer. Biochem Pharmacol 83: 443-451.

91. Salem EM, YarT, BamosaAO, Al-QuorainA, Yasawy MI, etal. (2010) Comparative study of Nigella sativa and triple therapy in eradication of Helicobacter pylori in patients with non-ulcer dyspepsia. Saudi J Gastroenterol 16: 207-214.

92. European Magazine of Cancer, October 1999

93. Top 27 amazing black seed oil benefits (Nigella Sativa) [https://www.selfhacked $\mathrm{com} / \mathrm{blog} /$ top-28-scientific-benefits-of-the-panacea-black-cumin-seed-nigellasativa/\#Stomach_cancer].

94. Yi T, Cho SG, Yi Z, Pang X, Rodriguez M, et al. (2008) Thymoquinone inhibits tumor angiogenesis and tumor growth through suppressing AKT and extracellular signal-regulated kinase signalling pathways. Mol Cancer Therr 7 : 1789-1796.

95. Lei X, Lv X, Liu M, Yang Z, Ji M, et al. (2012) Thymoquinone inhibits growth and augments 5-fluorouracil-induced apoptosis in gastric cancer cells both in vitro and in vivo. Biochem Biophys Res Commun 417: 864-868.

96. Black Seed (Nigella sativa): A cure for every disease [http://www.islamweb.net/ en/article/157049/black-seed-nigella-sativa-a-cure-for-every-disease].

97. Salim El, Fukushima S (2003) Chemopreventive potential of volatile oil from black cumin (Nigella sativa L.) seeds against rat colon carcinogenesis. Nutr Cancer 45: 195-202.

98. Norwood AA, Tan M, May M, Tucci M, Benghuzzi H (2006) Comparison of potential chemotherapeutic agents, green tea, and thymoquinone on colon cancer cells. Biomed Sci Instrum 42: 350-356.

99. Rooney S, Ryan MF (2005) Modes of action of alpha-hederin and thymoquinone active constituents of Nigella sativa, against HEp-2 cancer cells. Anticancer Res 25: 4255-4259.

100.Salim LZ, Mohan S, Othman R, Abdelwahab SI, Kamalidehghan B, et al. (2013) Thymoquinone induces mitochondria-mediated apoptosis in acute lymphoblastic leukaemia in vitro. Molecules 18: 11219-11240.

101. Thabrew MI, Mitry RR, Morsy MA, Hughes RD (2005) Cytotoxic effects of a decoction of Nigella sativa, Hemidesmus indicus and Smilax glabra on human hepatoma HepG2 cells. Life Sci 77: 1319-1330.

102. Khan N, Sultana S (2005) Inhibition of two stage renal carcinogenesis oxidative damage and hyper-proliferative response by Nigella sativa. Eur J Cancer Prev 14: 159-168.

103. Ethanol Medical Magazine, April 2000

104. Swamy SM, Huat BT (2003) Intracellular glutathione depletion and reactive oxygen species generation are important in alpha-hederin-induced apoptosis of P388 cells. Mol Cell Biochem 24: 127-139.

105.Al-Sheddi ES, Farshori NN, Al-Oqail MM, Musarrat J, Al-Khedhairy AA, et al (2014) Cytotoxicity of Nigella sativa seed oil and extract against human lung cancer cell line. Asian Pac J Cancer Prev 15: 983-987.

106. Linjawi SA, Khalil WK, Hassanane MM, Ahmed ES (2015) Evaluation of the protective effect of Nigella sativa extract and its primary active component thymoquinone against DMBA-induced breast cancer in female rats. Arch Med Sci 11: $220-229$

107. Black cumin increases the effectiveness of many types of breast cancer treatment (2015) [http://foodforbreastcancer.com/news/black-cumin increases-the-effectiveness-of-many-types-of-breast-cancer-treatment] 
Citation: Deena HAS, Hussain MM (2018) Prophetic Chemo Is the Safest, Cheapest and Most Effective Alternative to Modern Chemotherapy for the Cure of all Forms of Cancers - A Review. J Cancer Sci Ther 10: 090-104. doi: 10.4172/1948-5956.1000525

108. 108. Woo CC, Hsu A, Kumar AP, Sethi G, Tan KH (2013) Thymquinone inhibits tumor growth and induces apoptosis in a breast cancer xenograft mouse model: The role of p38 MAPK and ROS. PLoS One 8: e75356.

109. Thomas J (2014) We lost the war on cancer - Review of alternative cancer therapies. Editor Brian Shilhavy, USA, Kindle Edition, Sophia Media.

110. Holy Qur'an, Chapter Ash-Shuara, 26:80

111. Holy Qur'an, Chapter Ya-Sin, 36:12

112. Holy Qur'an, Chapter Al-Waqiah, 56: 83-85

113. Khan MA, Chen HC, Tania M, Zhang DZ (2011) Anticancer activities of Nigella Sativa (Black Cumin), Afr J Tradit Complement Altern Med 8: 226-232.

114. Bamosa AO, Kaatabi H, Lebdaa FM, Elq AM, Al-Sultanb A (2010) Effect of Nigella sativa seeds on the glycemic control of patients with type 2 diabetes mellitus. Indian J Physiol Pharmacol 54: 344-354.

115. Clark I (2014) Black cumin seed oil: Your ultimate life elixir. [http://www. activationproducts.com/marine-phytoplankton-supplement/black-cuminhealing/].

116. Motaghed M, Al-Hassan FM, Hamid SS (2013) Cellular responses with thymoquinone treatment in human breast cancer cell line MCF-7. Pharmacognosy Res 5: 200-206.

117. Ait Mbarek L, Mouse AH, El-Abbadi N, Bensalah M, Gamouh A, et al. (2007) Anti-tumor properties of blackseed (Nigella sativa L.) extracts, Braz J Med Biol Res 40: 839-847.

118. Racoma IO, Meisen WH, Wang QE, Kaur B, Wani AA (2013) Thymoquinone inhibits autophagy and induces cathepsin-mediated, caspase-independent cell death in glioblastoma cells. PLoS One 8: e72882.

119. Holy Bible, Isaiah, 28: 25, 27 New King James Version.

120. Sahih Al-Bukhari, Chapter 71, Disease, patient and treatment.

121. Sahih Muslim, Chapter Salam, Hadith No. 5579.

122.Za'adul Ma'ad, Chapter instruction to receive prescription from experienced physician, Hadith, No. 4/121. 